\title{
Surface Anchoring on Lactococcus lactis by Covalent Isopeptide Bond
}

\author{
Tina Vida Plavec ${ }^{1,2}$ and Aleš Berlec ${ }^{2, *}$ \\ ${ }^{1}$ Faculty of Pharmacy, University of Ljubljana, Aškerčeva 7, Ljubljana, Slovenia \\ ${ }^{2}$ Department of Biotechnology, Jožef Stefan Institute, Jamova 39, Ljubljana, Slovenia \\ *Corresponding author: E-mail: ales.berlec@ijs.si \\ + 38614773754
}

Received: 04-24-2018

Dedicated to the memory of Prof. Dr. Igor Kregar

\begin{abstract}
Display of recombinant proteins on the bacterial surface is an emerging research area with wide range of potential biotechnological applications. Because of its GRAS (generally recognized as safe) status, lactic acid bacterium Lactococcus lactis represents an attractive host for surface display and promising vector for in situ delivery of bioactive proteins. The present study focused on finding a new alternative approach for surface display on Lactoccocus lactis. We developed a system that enables the formation of irreversible isopeptide bonds on the surface of Lactococus lactis. This was achieved through the following two protein/peptide pairs, SpyCatcher/SpyTag and SnoopCatcher/SnoopTag. ${ }^{1-3}$ Attachment of tagged model protein B domain to the cell surface of Lactococccus lactis displaying the corresponding catcher protein was demonstrated using flow cytometry. We demonstrated effective use of aforementioned protein anchors which thus represent a promising alternative to established approaches for surface display on Lactoccocus lactis.
\end{abstract}

Keywords: Surface display; Lactococcus lactis; isopeptide bond

\section{Introduction}

Display of recombinant proteins on bacterial surface offers a variety of possible biotechnological applications. Proteins-displaying bacteria can act as bioadsorbents, biosensors, biocatalysts or oral vaccines. They can be used in antibody production and in peptide screening. ${ }^{4-6}$ Several lactic acid bacteria (LAB) are probiotics and are therefore considered valuable hosts in biotechnology due to their beneficial influence on health. ${ }^{7,8}$ Because of the "generally recognized as safe" (GRAS) status which confirms their safety, LAB are attractive not only for industrial application but also therapeutically. ${ }^{9}$ Display of heterologous proteins on the surface of LAB has already been exploited in therapy for the preparation of mucosal vaccines. ${ }^{10-12}$ Moreover, beneficial effects in inflammatory bowel disease could be achieved when displaying binding molecules directed against pro-inflammatory molecules such as TNFa. ${ }^{13-17}$

Different approaches can be exploited for displaying a protein on the bacterial surface. The protein to be dis- played is usually fused to an anchoring motif. ${ }^{14,18}$ Five different types of surface anchoring domains have been described for LAB: transmembrane domains, LPXTG-type domains, lysin motif (LysM) domains, surface layer proteins and lipoprotein anchors. ${ }^{19-21}$ The most frequently applied surface anchoring domains in prototype LAB, Lactococcus lactis, are the C-terminal part of endogenous AcmA, enabling non-covalent anchoring through peptidoglycan binding LysM repeats, ${ }^{22-25}$ and the LPXTG sequence of M6 protein of Streptococcus pyogenes enabling covalent anchoring. ${ }^{26,27}$ Despite these available options, alternative surface display approaches are being sought.

Recently, two peptide/protein pairs known as SpyTag/SpyCatcher, from Streptococcus pyogenes, and SnoopTag/SnoopCatcher, from Streptococcus pneumoniae have been developed. ${ }^{1-3}$ Interaction between the peptide and the protein leads to the formation of an irreversible isopeptide bond. The reaction is high-yielding and fast while the bond is highly stable. It can survive extreme $\mathrm{pH}$, high ionic strength and exposure to detergents. ${ }^{1,28,29}$ Stable bond formation enables combinatorial assembly of multi- 


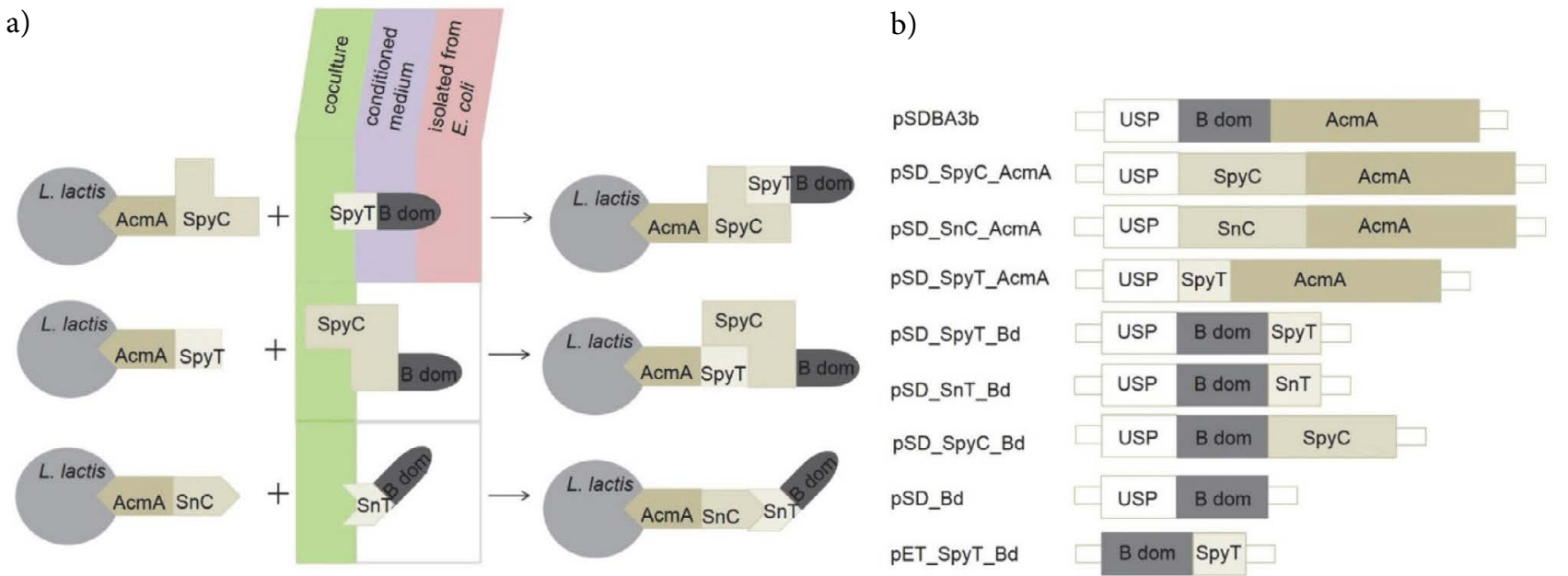

Fig. 1. The principle of surface display of B domain on L. lactis by the formation of isopeptide bond (A), and the gene constructs prepared for its implementation (B). A: Surface displayed SpyCatcher (SpyC), SpyTag (SpyT), or SnoopCatcher (SnC), all anchored via AcmA on L. lactis, bind fusion proteins consisting of SpyT, SpyC, or SnoopTag (SnT), respectively, and B domain. The fusion proteins were produced by L. lactis co-culture, were extracted from L. lactis conditioned medium, or were isolated from E. coli. B: Gene constructs for lactococcal surface display and isopeptide bond formation. USP: gene for Usp45 signal peptide for secretion to the growth medium (84 bp). B dom: gene for reporter protein B domain of staphylococcal protein A (174 bp). SpyC: gene for protein SpyCatcher which binds SpyT (348 bp). SnC: gene for protein SnoopCatcher which binds SnT (336 bp). SpyT: gene for peptide SpyTag (39 bp). SnT: gene for peptide SnoopTag (36 bp). AcmA: gene for C-terminal part of AcmA protein-containing 3 LysM repeats for surface anchoring to L. lactis (642 bp).

protein constructs, and opens an opportunity to use this approach in vaccine production, enzyme substrate channeling, antibody polymerization, cell signaling activation, and biomaterials. ${ }^{1,30}$ The key properties of isopeptide binding are simple and fast procedure, irreversible and stable bond, specificity, and cysteine independence; the latter offering the possibility to use the approach in reducing environment. $^{3}$

The goal of the present study was to develop a system for surface display on recombinant LAB L. lactis by applying the isopeptide bond formation (Fig. 1a). This was achieved by preparing genetic constructs consisting of surface anchor, elements of SpyTag/SpyCatcher or SnoopTag/ SnoopCatcher pairs and model passenger protein B domain (Fig. 1b). ${ }^{13} \mathrm{~B}$ domain is one out of five antibody-binding domains of staphylococcal protein A that can bind antibodies via their Fc region. ${ }^{13}$ The fusion proteins were expressed either in L. lactis or in E. coli, and assembled on the surface of $L$. lactis, as confirmed by surface localization of $\mathrm{B}$ domain.

\section{Experimental}

\section{1. Bacterial Strains, Media and Culture Conditions}

Bacterial strains used in this study are listed in Table 1. E. coli strains DH5a and BL21 (DE3) were grown at $37^{\circ} \mathrm{C}$, with aeration in lysogeny broth (LB) medium supplemented with either ampicillin $(100 \mu \mathrm{g} / \mathrm{mL})$ or kanamycin $(50 \mu \mathrm{g} /$ $\mathrm{mL}$ ). L. lactis NZ9000 was grown in M-17 medium (Mer- ck) supplemented with $0.5 \%$ glucose (GM-17) and chloramphenicol $(10 \mu \mathrm{g} / \mathrm{mL})$ at $30^{\circ} \mathrm{C}$ without aeration.

\section{2. Molecular Cloning}

Plasmid DNA was isolated with NucleoSpin Plasmid (Macherey and Nagel, Düren, Germany), with an additional lysozyme treatment step for L. lactis. Lactococci were transformed with electroporation using a Gene Pulser II apparatus (Biorad, Hercules, USA) according to the $\mathrm{MoBiTec} \mathrm{GmbH}$ (Goettingen, Germany) instructions. Nucleotide sequencing was performed by GATC (Constance, Germany).

Gene for SpyTag in fusion with B domain for expression in E. coli was amplified from pSDBA3b by PCR using primers B-F-NcoI-Spy and B-R-XhoI, cloned to PGEM-T Easy and then to pET28a via restriction enzymes NcoI/ XhoI, yielding pET_SpyT_Bd. Gene for SpyTag in fusion with $\mathrm{B}$ domain for secretion from $L$. lactis was amplified from pSDBA3b by PCR using primers B-F-BamHI and B-R-Kpn-Sy-Xba. Gene for SnoopTag in fusion with B domain was prepared likewise using primers B-F-BamHI and B-R-Kpn-So-Xba. Both were first cloned to plasmid pGEM-T Easy and then to plasmid pSDBA3b via restriction enzymes BamHI/XbaI, yielding pSD_SpyT_Bd and pSD_SnT_Bd. Gene for B domain for secretion from $L$. lactis was amplified from $\mathrm{pSDBA} 3 \mathrm{~b}$ by PCR using primers B-F-BamHI and B-R-Xba, first cloned to plasmid pGEM-T Easy and then to plasmid pSDBA3b via restriction enzymes BamHI/XbaI, yielding pSD_Bd (Table 2-4).

Genes for SpyCatcher and SnoopCatcher were designed and synthesized de novo as gBlocks (Table 4) by 
Table 1. Strains used in this study

\begin{tabular}{|c|c|c|}
\hline Strain & Relevant features or sequence & Reference \\
\hline \multicolumn{3}{|l|}{ E. coli } \\
\hline $\mathrm{DH} 5 a$ & 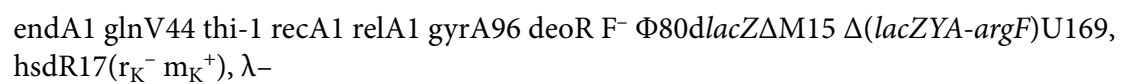 & Invitrogen \\
\hline \multicolumn{3}{|c|}{ 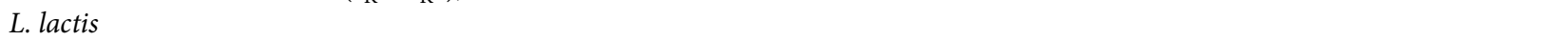 } \\
\hline NZ9000 & MG1363 nisRK $\Delta p e p N$ & NIZO \\
\hline
\end{tabular}

Table 2. Plasmids used in this study

\begin{tabular}{lll}
\hline Plasmid & Relevant features or sequence & Reference \\
\hline pET28a & Kan $^{\mathrm{r}}$ E. coli expression vector & Novagen \\
pGEM-T Easy & $\mathrm{Ap}^{\mathrm{r}}$, cloning vector for PCR products & Promega \\
pSDBA3b & pNZ8148 containing gene fusion of $s p_{\mathrm{Usp} 45}, b$-dom and $a c m A 3 b$ & 31 \\
pNZ8148 & pSH71 derivative, $\mathrm{P}_{\text {nisA }}, \mathrm{Cm}^{\mathrm{r}}$, nisin-controlled expression & This work \\
pET_SpyT_Bd & pET28a containing gene fusion of $s p y t a g$ and $b$-dom & This work \\
pSD_SpyC_AcmA & pNZ8148 containing gene fusion of $s p_{\mathrm{Usp} 45}$, spycatcher and $a c m A 3 b$ & This work \\
pSD_SnC_AcmA & pNZ8148 containing gene fusion of $s p_{\mathrm{Usp} 45}$, snoopcatcher and $a c m A 3 b$ & This work \\
pSD_Bd & pNZ8148 containing gene fusion of $s p_{\mathrm{Usp} 45}$ and $b$-dom & This work \\
pSD_SpyT_Bd & pNZ8148 containing gene fusion of $s p_{\mathrm{Usp} 45}$, spytag and $b$-dom & This work \\
pSD_SnT_Bd & pNZ8148 containing gene fusion of $s p_{\mathrm{Usp} 45}$, snooptag and $b$-dom & This work \\
pSD_SpyC_Bd & pNZ8148 containing gene fusion of $s p_{\mathrm{Usp} 45}, s p y c a t c h e r$ and $b$-dom & This work \\
pSD_SpyT_AcmA & pNZ8148 containing gene fusion of $s p_{\mathrm{Usp} 45}, s p y t a g$ and $a c m A 3 b$ & \\
\hline
\end{tabular}

Table 3. Primers used in this study

\begin{tabular}{|c|c|c|}
\hline Primer & Relevant features or sequence & Reference \\
\hline B-F-NcoI-Spy & $\begin{array}{l}\text { 5’-CCATGGCTCATATTGTAATGGTCGATGCATATAAACCAACCAAAGCTGATAA } \\
\text { CAAATTCAACAAAGAAC-3' }\end{array}$ & This work \\
\hline B-R-XhoI & 5’-CTCGAGTTTTGGTGCTTGTGCATC-3’ & This work \\
\hline B-F-BamHI & 5'-AGGATCCGCTGATAACAAATTCAAC-3' & This work \\
\hline B-R-Kpn-Sy-Xba & $\begin{array}{l}\text { 5'TTCTAGATTATTTGGTTGGTTTATATGCATCGACCATTACA } \\
\text { ATATGAGCGGTACCTTTTGGTGCTTGTGCATC-3' }\end{array}$ & This work \\
\hline B-R-Kpn-So-Xba & $\begin{array}{l}\text { 5'-TTCTAGATTATTTGTTAACTTTAATAAATTCGATGTCACCCA } \\
\text { ACTTGGTACCTTTTGGTGCTTGTGCATC-3' }\end{array}$ & This work \\
\hline B-R-Xba & 5’-TTCTAGATTATTTTGGTGCTTGTGCATC-3’ & This work \\
\hline SpyC-F-Kpn & 5’A & This work \\
\hline SpyC-R-Xba & 5’-TTCTAGATTAAATATGAGCATCACCTTTTGTTG-3' & This work \\
\hline AcmA-F-Bam-SpyT & $\begin{array}{l}\text { 5'AGGATCCGCTCATATTGTAATGGTCGATGCATATAAACCAACCAAA } \\
\text { TCTGGTGGCTCGACAACC-3' }\end{array}$ & This work \\
\hline AcmA-R-Xba & 5’-TTCTAGATTATTTTATTCGTAGATACTGACC-3’ & This work \\
\hline Spy-F-Bam & 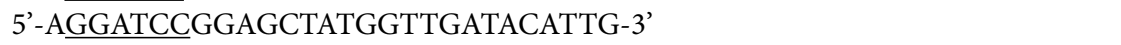 & This work \\
\hline Spy-R-Eco & 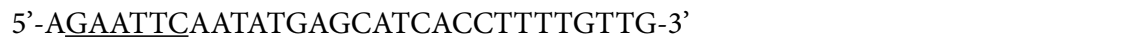 & This work \\
\hline Sno-F-Bam & 5’-AGGATCCAAACCTTTGCGTGGTGCAG-3’ & This work \\
\hline Sno-R-Eco & 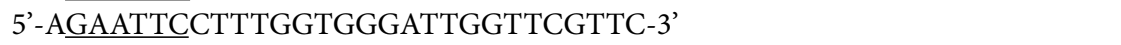 & This work \\
\hline
\end{tabular}

IDT (Leuven, Belgium). Gene for secretion of SpyCatcher-B domain fusion from $L$. lactis was amplified from gBlock by PCR using primers SpyC-F-Kpn and SpyC-RXba, cloned to pGEM-T Easy and then to pSD_SpyT_Bd via restriction enzymes $\mathrm{KpnI} / \mathrm{XbaI}$, yielding $\mathrm{pSD} \_$SpyC_ Bd (Table 1-4).

Genes for the surface display of SpyCatcher and SnoopCatcher were amplified from gBlocks using primer pairs Spy-F-Bam/Spy-R-Eco and Sno-F-Bam/Sno-R-Eco, respectively, and were cloned first to pGEM-T Easy and then to plasmid pSDBA3b via restriction enzymes EcoRI/ BamHI, yielding pSD_SpyC_AcmA and pSD_SnC_ AcmA, respectively. Gene for the display of SpyTag on the L. lactis surface was amplified from pSDBA3b by PCR using primers AcmA-F-Bam-SpyT and AcmA-R-Xba, cloned to $\mathrm{pGEM}-\mathrm{T}$ Easy and then to pSD_SpyC_AcmA via re- 
Table 4. Genes used in this study

\begin{tabular}{lll}
\hline Gene & Relevant features or sequence & Reference \\
\hline spycatcher & GGATCCGGAGCTATGGTTGATACATTGTCAGGTTTATCATCAGAACAA \\
& GGACAAAGTGGAGATATGACTATTGAAGAAGATTCTGCTACACATATTAAA \\
TTTTCAAAACGTGATGAAGATGGAAAAGAATTAGCAGGTGCTACTATGGA & ATTGCGTGATTCATCAGGTAAAACAATTTCAACTTGGATTTCAGATGGACAA \\
& GTTAAAGACTTTTATCTGTACCCTGGAAAATATACTTTCGTTGAAACAGCAGCA \\
& CCTGACGGATACGAAGTTGCTACTGCTATCACTTTTACAGTTAACGAACAAGG \\
TCAAGTTACAGTTAATGGTAAAGCAACAAAAGGTGATGCTCATATTGAATTC & GGATCCAAACCTTTGCGTGGTGCAGTCTTCTCATTACAAAAACAACATCC \\
snoopcatcher & AGACTACCCTGATATTTATGGTGCCATTGATCAAAATGGTACTTATCAGAA \\
& TGTTCGAACTGGTGAAGACGGAAAATTGACTTTTAAGAATTTGAGTGACGG \\
& TAAATATCGTTTATTCGAAAACAGTGAACCAGCTGGATATAAGCCAGTA \\
& CAAAATAAACCTATTGTCGCATTTCAAATTGTAAACGGTGAAGTTAGAGACG \\
TTACTTCTATTGTACCTCAGGATATTCCTGCTACTTATGAATTTACTAA & TGGAAAACATTATATTACGAA work \\
spytag & CGAACCAATCCCACCAAAGGAATTC \\
& GCTCATATTGTAATGGTCGATGCATATAAACCAACCAAA \\
& AAGTTGGGTGACATCGAATTTATTAAAGTTAACAAA
\end{tabular}

striction enzymes BamHI/XbaI, yielding pSD_SpyT_ AcmA (Table 2-4).

\section{3. Expression of SpyTag-B Domain Fusion in E.coli}

$100 \mu \mathrm{L}$ of overnight culture of E. coli BL21 (DE3) harboring plasmid pET_SpyT_Bd was diluted (1:100) in $10 \mathrm{~mL}$ of fresh LB medium and, to determine optimal expression conditions, various parameters were tested: incubation temperature $37^{\circ} \mathrm{C}$ or $25^{\circ} \mathrm{C}$, induction at optical densities $\left(\mathrm{A}_{600}\right) 0.5$ or 1.0, induction with IPTG in concentration of 0.5 and $1.0 \mathrm{mM}$.

Large-scale expression of SpyTag-B domain fusion was performed by diluting $10 \mathrm{~mL}$ of overnight culture of $E$. coli BL21 (DE3) harboring plasmid pET_SpyT_Bd in $1 \mathrm{~L}$ of fresh LB medium. The culture was grown to optical density $\mathrm{A}_{600}=0.5$ at $37^{\circ} \mathrm{C}$. At that point, the expression of SpyTag-B domain fusion, additionally tagged with hexa-histidine (H6), was induced by the addition of 0.5 mM IPTG for $3 \mathrm{~h}$ at $37^{\circ} \mathrm{C}$; the conditions that were found to be the most effective in preliminary screen.

\section{4. Purification of SpyTag-B Domain With Hexa-histidine (H6) Tag}

The E. coli culture expressing SpyTag-B domain with hexa-histidine (H6) tag was centrifuged at $5000 \times \mathrm{g}$ for 20 min and the pellet resuspended in $20 \mathrm{~mL}$ of equilibration/ wash $(\mathrm{Eq} / \mathrm{W})$ buffer $\left(50 \mathrm{mM} \mathrm{NaH} \mathrm{PO}_{4}, 300 \mathrm{mM} \mathrm{NaCl}, \mathrm{pH}\right.$ 7.0). The cells were lysed with a cycle of freezing and thawing, and with 3 cycles of 5 min sonication with a UPS200S sonifier (Hielscher, Teltow, Germany). After cell lysis, the suspension was centrifuged at $15000 \times \mathrm{g}$ for $20 \mathrm{~min}$ and the supernatant stored. SpyTag-B domain with H6 tag was iso- lated with BD Talon metal affinity resin (BD Biosciences), using batch/gravity-flow column purification and imidazole elution (elution buffer: $50 \mathrm{mM} \mathrm{NaH}{ }_{2} \mathrm{PO}_{4}, 300 \mathrm{mM} \mathrm{NaCl}$, $150 \mathrm{mM}$ imidazole, $\mathrm{pH}$ 7.0) according to the manufacturer's instructions. Eluted fractions were analyzed by SDS-PAGE, pooled and concentrated by ultrafiltration using Amicon Ultra $1 \mathrm{KDa}$ cut off (Merck Millipore; Darmstadt, Germany). Purified fusion protein was dialyzed against PBS.

\section{5. Expression of Fusion Proteins in L. lactis}

Overnight cultures of L. lactis NZ9000 harboring pSD_SpyC_AcmA, pSD_SnC_AcmA, pSD_SpyT_AcmA, pSD_SpyT_Bd, pSD_SnT_Bd, pSD_SpyC_Bd, or pSD_Bd were diluted (1:100) in $10 \mathrm{~mL}$ of fresh GM-17 medium and grown to optical density $\mathrm{A}_{600}=0.8-1.0$. Fusion protein expression was induced with $25 \mathrm{ng} / \mathrm{mL}$ nisin (Fluka AG, Buchs, Switzerland) for $3 \mathrm{~h}$ at $30^{\circ} \mathrm{C}$. After incubation, 1 $\mathrm{mL}$ of culture was stored at $4{ }^{\circ} \mathrm{C}$ for flow cytometric analysis. The remaining cell culture was centrifuged at $5000 \times \mathrm{g}$ for $10 \mathrm{~min}$.

\section{6. Formation of Isopeptide Bond Between SpyTag and SpyCatcher / SnoopTag and SnoopCatcher}

In order to enable binding of E. coli-expressed SpyTag-B domain to L. lactis with surface displayed SpyCatcher, we centrifuged $20 \mu \mathrm{L}$ of the cell culture of L. lactis with surface displayed SpyCatcher for $5 \mathrm{~min}$ at $5000 \times \mathrm{g}$ at $4{ }^{\circ} \mathrm{C}$, resuspended the pellet in $500 \mu \mathrm{L}$ of purified E. coli-expressed SpyTag-B domain with concentration of $0.4 \mathrm{mg} /$ $\mathrm{mL}$ and incubated for $2 \mathrm{~h}$ at RT with constant shaking.

To enable binding of SpyTag-B domain from L. lactis conditioned medium to $L$. lactis with surface displayed 
SpyCatcher, we separately cultured the SpyTag-B domain-secreting L. lactis and SpyCatcher-displaying L. lactis. The producer cells of SpyTag-B domain were removed and the conditioned medium containing SpyTag-B domain fusion protein was stored. $20 \mu \mathrm{L}$ of L. lactis cell culture with surface displayed SpyCatcher was centrifuged for $5 \mathrm{~min}$ at $5000 \times \mathrm{g}$ at $4{ }^{\circ} \mathrm{C}$, resuspended in $500 \mu \mathrm{L}$ of conditioned medium containing SpyTag-B domain and incubated overnight at RT with constant shaking.

Binding of SpyTag-B domain secreted from L. lactis to SpyCatcher displayed on L. lactis was also achieved during co-culturing of the two strains. $100 \mu \mathrm{L}$ of overnight cultures of $L$. lactis NZ9000 harboring pSD_SpyT_Bd and pSD_SpyC_AcmA were concomitantly added to $10 \mathrm{~mL}$ of fresh GM-17 medium. Simultaneous expression of the two fusion proteins was induced with nisin. Similarly, binding of SpyCatcher-B domain secreted from L. lactis to SpyTag displayed on L. lactis was achieved by co-culturing $L$. lactis NZ9000 harboring pSD_SpyC_Bd and pSD_SpyT_AcmA, as well as binding of SnoopTag-B domain secreted from $L$. lactis to SnoopCatcher displayed on L. lactis by co-culturing L. lactis NZ9000 harboring pSD_SnC_AcmA and pSD_SnT_Bd.

\section{7. SDS-PAGE and Western Blot}

SDS PAGE was performed with a Mini-Protean II apparatus (Bio-Rad, Hercules, USA). Samples were thawed in an ice bath, briefly sonicated with UPS200S sonicator (Hielscher, Teltow, Germany), mixed with $2 \times$ Laemmli Sample buffer and DTT, and denatured by heating at $100^{\circ} \mathrm{C}$ before loading. Page Ruler Plus (Fermentas, St. Leon-Rot, Germany) pre-stained standard was used for molecular weight comparison. Proteins were stained with Coomassie Brilliant Blue or transferred to polyvinylidene fluoride (PVDF) membranes (Immobilon-P, Millipore) using wet transfer at $100 \mathrm{~V}$ for 90 minutes. Membranes were blocked in 5\% non-fat dried milk in TBS with $0.05 \%$ Tween-20
(TBST; $50 \mathrm{mM}$ Tris-HCl, $150 \mathrm{mM} \mathrm{NaCl}, 0.05 \%$ Tween 20, $\mathrm{pH} 7.5)$ and incubated overnight at $4{ }^{\circ} \mathrm{C}$ with goat anti-protein A antibody (1:2000, Abcam) in 5\% non-fat dried milk in TBST. Following three washes with TBST, membranes were incubated for $2 \mathrm{~h}$ with HRP conjugated secondary donkey anti-goat IgG (1:5000, Jackson ImmunoResearch) in 5\% non-fat dried milk in TBST. After three further washes with TBST, membranes were incubated with Lumi-Light chemiluminescent reagent (Roche). Images were acquired using ChemiDoc MP Imaging System (BioRad).

\section{8. Flow Cytometry}

For flow cytometry $20 \mu \mathrm{L}$ of cell culture in stationary phase was added to $500 \mu \mathrm{L}$ of Tris-buffered saline (TBS; 50 $\mathrm{mM}$ Tris- $\mathrm{HCl}, 150 \mathrm{mM} \mathrm{NaCl}, \mathrm{pH} 7.5$ ) and centrifuged for 5 $\min$ at $5000 \times \mathrm{g}$ at $4{ }^{\circ} \mathrm{C}$. The pellet was resuspended in 500 $\mu \mathrm{L}$ of TBS with $1 \mu \mathrm{L}$ of fluorescein-5-isothiocyanate (FITC)-conjugated human IgG antibody (Jackson ImmunoResearch, West Grove, USA) that binds the B domain via $\mathrm{Fc}$ region. After $2 \mathrm{~h}$ of incubation at $\mathrm{RT}$ with constant shaking at $100 \mathrm{rpm}$, cells were washed three times with $200 \mu \mathrm{L}$ $0.1 \%$ TBST and finally resuspended in $500 \mu \mathrm{L}$ TBS. Samples were analyzed with a flow cytometer (FACS Calibur; Becton Dickinson, Franklin Lakes, USA) using excitation at 488 $\mathrm{nm}$ and emission at $530 \mathrm{~nm}$ in the FL1 channel. The geometric mean fluorescence intensity (MFI) of at least 20000 bacterial cells in the appropriate gate was measured. The average of at least three independent experiments was considered. All the samples went through the same procedures of preparation for flow cytometry analysis.

\subsection{Statistical Analyses}

Statistical analyses were performed with GraphPad Prism 5.0 software. Student's t test was used to compare the significance of differences between B domain-displaying bacteria and control. a)

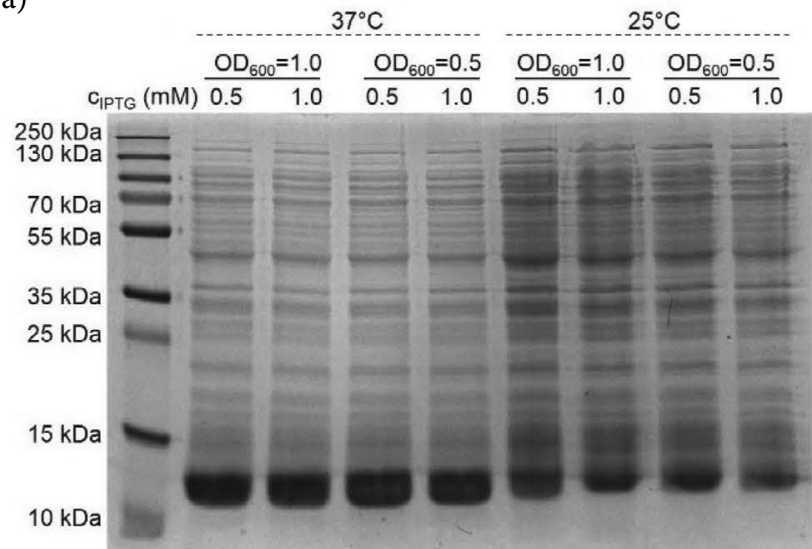

b)

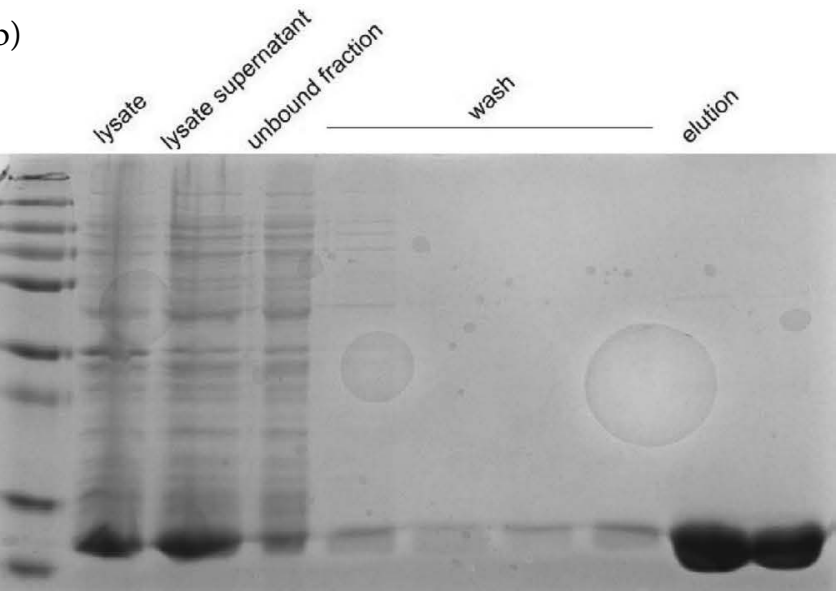

Fig. 2. Coomassie-stained SDS-PAGE of E. coli expressing SpyTag-B domain under different culturing conditions (A) and fractions obtained after IMAC purification of SpyTag-B domain from cell lysate (B). 


\section{Results}

\section{1. Expression and Purification of Recombinant SpyTag-B Domain from E. coli}

Gene for SpyTag-B domain, possessing affinity for the $\mathrm{Fc}$ region of human IgG, was cloned into the pET28a plasmid (Fig. 1b) in order to express the protein in E. coli and obtain it in sufficient amount and purity. Recombinant SpyT-B domain fusion protein with $\mathrm{H} 6$ tag was produced in E. coli BL21 DE3. Various expression conditions (growth at $37^{\circ} \mathrm{C}$ and $25^{\circ} \mathrm{C}$, induction at optical densities $\left(\mathrm{A}_{600}\right) 0.5$ and 1 , induction with IPTG concentration of 0.5 and $1.0 \mathrm{mM}$ ) were tested. The highest total amount of SpyT-B domain expression was achieved by growing the bacteria at $37^{\circ} \mathrm{C}$ to $\mathrm{A}_{600}=0.5$ or 1.0 , followed by induction with 0.5 or $1 \mathrm{mM} \mathrm{IPTG}$ for $3 \mathrm{~h}$ at $37^{\circ} \mathrm{C}$ (Fig. 2a). The majority of the fusion protein was produced in the soluble form as it could be detected in the soluble fraction (supernatant) of the cell lysate (Fig. 2b). SpyTag-B domain was isolated with immobilized metal affinity chromatography (IMAC) (Fig. 2b).

\section{2. Binding of E. coli-expressed SpyTag-B \\ Domain to L. Lactis with Surface Displayed SpyCatcher}

SpyCatcher in fusion with Usp45 secretion signal ${ }^{26}$ and the surface anchoring C-terminal domain of AcmA was displayed on the surface of L. lactis as previously reported for other proteins. ${ }^{13,35-37}$ Binding of SpyTag-B domain, isolated from $E$. coli, to recombinant $L$. lactis with surface displayed SpyCatcher was evaluated by flow cytometry using antibody recognizing B domain. Statistical-

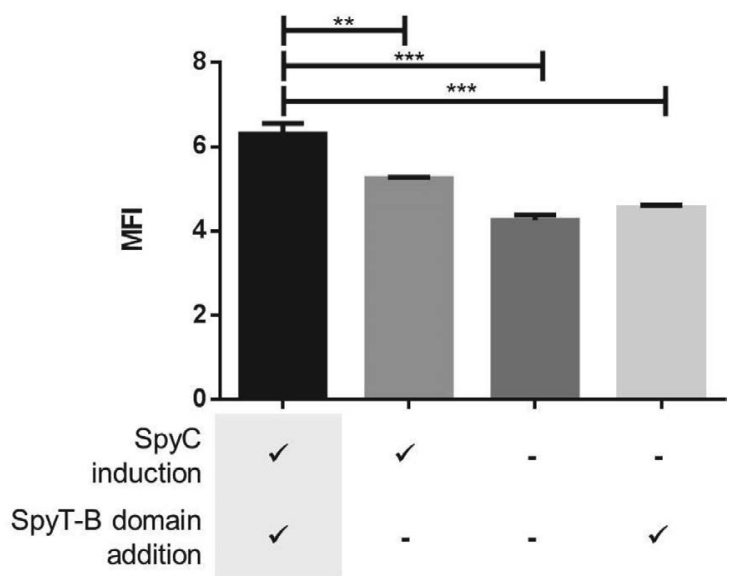

Fig. 3. Flow cytometric analysis of binding of SpyTag (SpyT)-B domain, isolated from E. coli, to L. lactis cells displaying SpyCatcher (SpyC) on their surface. FITC-conjugated human IgG was used for detection. Mean fluorescence intensity (MFI) value of SpyC-displaying bacteria with added SpyT-B domain was compared to those of the controls by using Student's $t$ test. ${ }^{* *} \mathrm{p}<0.01,{ }^{* * *} \mathrm{p}<0.001$. ly significant increase in MFI was observed when SpyT-B domain was incubated with $L$. lactis with induced SpyCatcher expression, in comparison to control non-induced $L$. lactis cells, or induced $L$. lactis cells without the addition of SpyT-B domain (19.9\%; Fig. 3).

\section{3. Binding of SpyTag-B Domain from $L$. lactis Conditioned Medium to L. lactis with Surface Displayed SpyCatcher}

SpyTag in fusion with B domain and Usp45 secretion signal (plasmid pSD_SpyT_Bd) was expressed in L. lactis under the control of NisA promoter ${ }^{38}$ and secreted to the growth medium. The producer cells were removed and the conditioned medium containing SpyTag-B domain fusion protein was incubated with $L$. lactis cells with surface displayed SpyCatcher (plasmid pSD_SpyC_AcmA). Low extent of binding was observed with flow cytometry using antibody recognizing B domain. Small statistically significant increase in MFI was reported when SpyTag-B domain was incubated with SpyCatcher-displaying L. lactis, in comparison to empty plasmid pNZ8148-containing control. No difference was observed when non-tagged $\mathrm{B}$ domain was incubated with SpyCatcher-displaying L. lactis (Fig. 4).

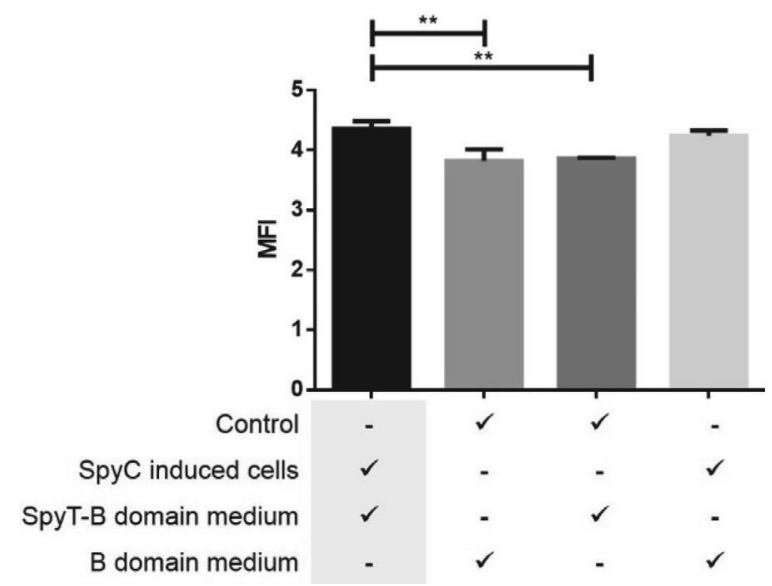

Fig. 4. Flow cytometric analysis of binding of L. lactis-secreted SpyTag (SpyT)-B domain to L. lactis-displaying SpyCatcher (SpyC). FITC-conjugated human IgG was used for detection. Mean fluorescence intensity (MFI) values of SpyC-displaying bacteria with added SpyT-B domain-containing medium were compared to those of the controls by using Student's $t$ test. ${ }^{\star} \mathrm{p}<0.05,{ }^{* *} \mathrm{p}<0.01$.

\section{4. Binding of SpyTag-B Domain Secreted from L. lactis to SpyCatcher Displayed on L. lactis During the Co-culturing of the Two Strains}

We co-cultured L. lactis secreting SpyTag-B domain fusion (plasmid pSD_SpyT_Bd) with L. lactis displaying SpyCatcher (plasmid pSD_SpyC_AcmA) to achieve immediate bond formation between SpyCatcher and SpyTag protein/peptide pair. Binding was evaluated with flow cy- 
tometry using antibody recognizing B domain. Statistically significant increase in MFI (40.1\%) was observed, when Spy-tagged B domain producing L. lactis was co-cultured with SpyCatcher-displaying L. lactis cells, in comparison to SpyCatcher-displaying L. lactis cells (Fig. 5).

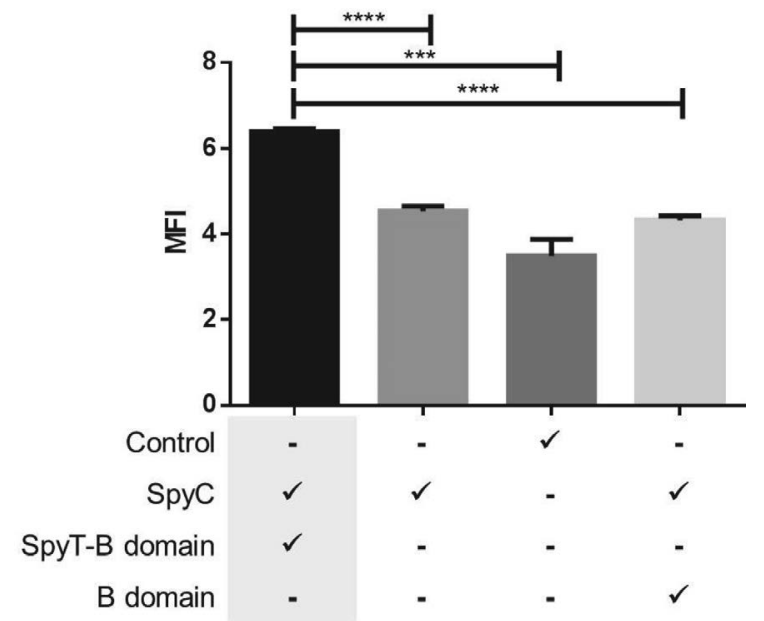

Fig. 5. Flow cytometric analysis of binding of L. lactis-secreted SpyTag (SpyT)-B domain to L. lactis cells displaying SpyCatcher (SpyC) on their surface after co-culturing of the two strains. FITC-conjugated human IgG was used for detection. Mean fluorescence intensity (MFI) values were compared to those of controls using Student's t test. ${ }^{* * *} \mathrm{p}<0.001,{ }^{* * * *} \mathrm{p}<0.0001$.

\section{5. Replacing Tag and Catcher: Binding of SpyCatcher-B Domain Secreted from L. lactis to SpyTag Displayed on L. lactis During Co-culturing of the Two Strains}

The location of interacting protein/peptide pair was reversed by engineering a strain of $L$. lactis to secrete the

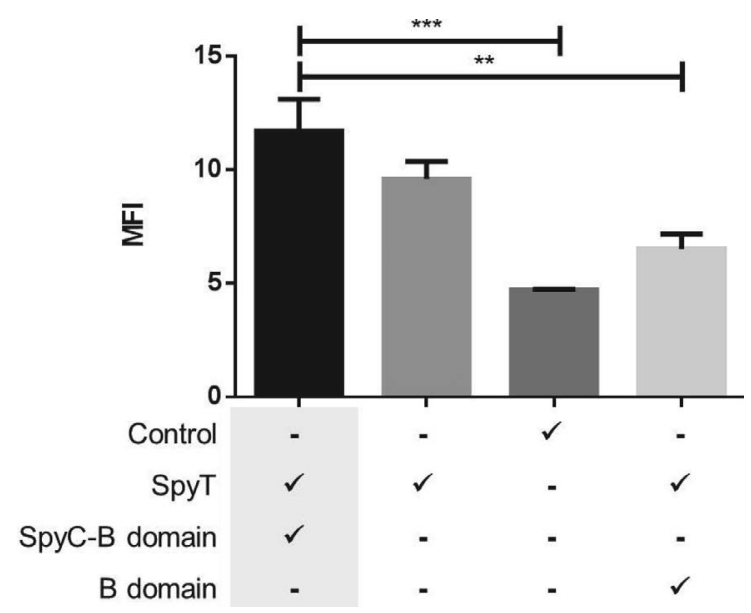

Fig. 6. Flow cytometric analyses of binding of L. lactis-secreted SpyCatcher (SpyC)-B domain to L. lactis cells displaying SpyTag (SpyT) on their surface. FITC-conjugated human IgG was used for detection. MFI: Mean fluorescence intensity. MFI values were compared to those of controls using Student's t test. ${ }^{* *} \mathrm{p}<0.01,{ }^{* * *} \mathrm{p}<0.001$.
SpyCatcher fusion protein, and another strain to display the SpyTag. SpyCatcher-B domain fusion-secreting L. lactis (plasmid pSD_SpyC_Bd) was co-cultured with SpyTag-displaying L. lactis (plasmid pSD_SpyT_AcmA). Statistically significant increase in MFI (22.0\%) was observed, when SpyCatcher-B domain producing L. lactis was co-cultured with SpyTag-displaying L. lactis cells, in comparison to SpyCatcher-displaying L. lactis cells (Fig. 6).

\section{6. Introducing SnoopCatcher and Tag: Binding of SnoopTag-B Domain Secreted from L. lactis to SnoopCatcher Displayed on L. lactis During Co-culturing of the Two Strains}

We co-cultured L. lactis secreting SnoopTag-B domain fusion (plasmid pSD_SnT_Bd) with L. lactis displaying SnoopCatcher (plasmid pSD_SnC_AcmA), respectively, to achieve immediate bond formation, as demonstrated previously for SpyCatcher/SpyTag pair. Binding was evaluated with flow cytometry using antibody recognizing B domain. Statistically significant increase in MFI (21.1\%) was observed, when Snoop-tagged B domain-producing $L$. lactis was co-cultured with SnoopTag-displaying L. lactis cells, in comparison to SnoopCatcher-displaying L. lactis cells (Fig. 7).

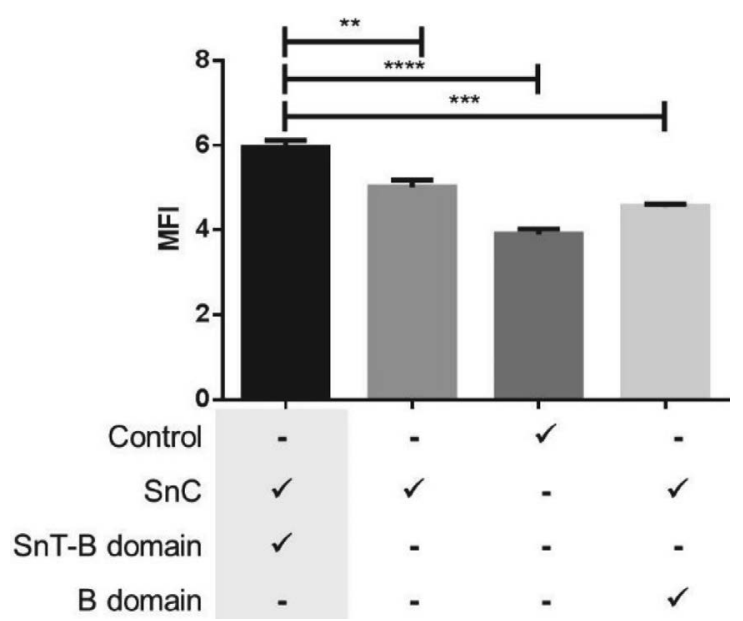

Fig. 7. Flow cytometric analysis of binding of L. lactis-secreted SnoopTag (SnoopT)-B domain to L. lactis cells displaying SnoopCatcher (SnoopC) on their surface after co-culturing of the two strains. FITC-conjugated human IgG was used for detection. Mean fluorescence intensity (MFI) values were compared to those of controls using Student's t test. ${ }^{* *} \mathrm{p}<0.01$, $^{* *} \mathrm{p}<0.001,{ }^{* * * *} \mathrm{p}<0.0001$.

\section{Discussion}

Isopeptide bond formation was applied to develop alternative surface display systems for LAB L. lactis by enabling a stable covalent bond between a peptide SpyTag 
and a protein SpyCatcher or, similarly, between a peptide SnoopTag and a protein SnoopCatcher. ${ }^{1,2}$ The peptide/ protein pair has already been employed to stabilize enzymes, for modular vaccine production, vaccine optimization and formation of catalytic biofilms. ${ }^{29,39}$

To test the feasibility of the isopeptide bond formation, we anchored one of the binding partners to the surface of L. lactis, by fusing it with Usp45 secretion signal and peptidoglycan-binding C-terminus of AcmA protein, as previously reported. ${ }^{13,35}$ The second binding partner was fused to a reporter protein $\mathrm{B}$ domain that we previously applied for the assessment of surface display. ${ }^{13,40} \mathrm{~B}$ domain fusion was isolated from $E$. coli or secreted from another recombinant $L$. lactis species (Fig. 1). Formation of the isopeptide bond resulted in the attachment of the B domain to the surface of $L$. lactis and was assessed by flow cytometry. We obtained statistically significant display of B domain on the surface of L. lactis with almost all the systems that were constructed.

Firstly, we expressed a fusion peptide SpyTag-B domain-His Tag in E. coli to obtain sufficient amount of the fusion protein following IMAC purification. Purified SpyTag-B domain-His Tag was added to SpyCatcher-displaying recombinant $L$. lactis. Statistically significant display of B domain, in comparison to the control, was determined. However, the binding was relatively weak and partially unspecific.

Secondly, we expressed SpyTag-B domain in L. lactis and directed it to the growth medium. After removal of the producer cells, the conditioned medium was incubated with SpyCatcher-displaying recombinant $L$. lactis. The display of B domain was lower than that achieved with SpyTag-B domain from E. coli and was not statistically significant. This could be due to the lower amount of the fusion protein in the conditioned medium. Moreover, there are several other factors in the medium that could hinder binding, for example $\mathrm{pH}$ value of the medium, and the presence of numerous other proteins and peptides. Even though SpyCatcher-SpyTag bond is claimed to be stable under a range of $\mathrm{pH}$ values $(5-8)^{29}$ it is possible that low $\mathrm{pH}$ of the conditioned medium hinders the bond formation. Additionally, numerous peptides in the conditioned medium might non-specifically interact with SpyCatcher.

Thirdly, we expected the formation of the isopeptide bond to be more probable if the Spy-tagged B domain was available immediately after induction of the surface display of SpyCatcher, as this would decrease the probability of unspecific interactions. Availability of Spy-tagged B domain was provided by co-culturing two species of L. lactis: one displaying SpyCatcher, and the other secreting SpyTag-B domain fusion. Thus achieved surface display of B domain was indeed higher than that achieved by the addition of SpyTag-B domain from E. coli or from the conditioned medium of $L$. lactis.

In the above examples the SpyCatcher was immobilized on the surface of $L$. lactis. To test the influence of the location of binding partners, we reversed the system by displaying SpyTag on L. lactis, and co-cultured the strain with $L$. lactis secreting SpyCatcher-B domain fusion protein. The display of B domain was again achieved; however due to relatively high unspecific binding of antibodies with SpyTag-displaying lactococci the display was not statistically significant.

Apart from SpyCatcher/SpyTag pair, the isopeptide bond can also be formed by combining SnoopCatcher and SnoopTag. We applied similar experimental setup as previously described for SpyCatcher/SpyTag by displaying SnoopCatcher on the surface of L. lactis and co-culturing the bacteria with a strain of recombinant $L$. lactis secreting SnoopTag-B domain fusion protein. Significant surface display of B domain was again observed; however there was no improvement over SpyCatcher/SpyTag pair.

\section{Conclusion}

In the present study we demonstrated, for the first time, the surface display of reporter protein on L. lactis by exploiting isopeptide bond-forming partners SpyCatcher and SpyTag, as well as SnoopCatcher and SnoopTag. The most effective display was obtained by anchoring SpyCatcher to the bacterial surface, and co-culturing the bacteria with a lactococcal strain that secreted Spy-tagged reporter protein. This represents a proof-of-principle for a new, highly flexible surface display system for L. lactis that warrants further studies with an intention to improve the extent of surface display.

\section{Acknowledgments}

This study was funded by the Slovenian Research Agency (grant number P4-0127).

\section{References}

1. G. Veggiani, T. Nakamura, M. D. Brenner, R. V. Gayet, J. Yan, C. V. Robinson, M. Howarth, Proc Natl Acad Sci U S A 2016, 113, 1202-7. DOI: https://doi.org/10.1073/pnas.1519214113

2. G. Veggiani, B. Zakeri, M. Howarth, Trends Biotechnol 2014,32, 506-12. DOI: https://doi.org/10.1016/j.tibtech.2014.08.001

3. B. Zakeri, J. O. Fierer, E. Celik, E. C. Chittock, U. SchwarzLinek, V. T. Moy, M. Howarth, Proc Natl Acad Sci U S A 2012, 109, E690-7. DOI: https://doi.org/10.1073/pnas.1115485109

4. S. Y. Lee, J. H. Choi, Z. Xu, Trends Biotechnol 2003, 21, 45-52. DOI: https://doi.org/10.1016/S0167-7799(02)00006-9

5. S. Stahl, M. Uhlen, Trends Biotechnol 1997, 15, 185-92. DOI: https://doi.org/10.1016/S0167-7799(97)01034-2

6. G. Georgiou, C. Stathopoulos, P. S. Daugherty, A. R. Nayak, B. L. Iverson, R. Curtiss, 3rd, Nat Biotechnol 1997, 15, 29-34. DOI: https://doi.org/10.1038/nbt0197-29 
7. V. Laroute, H. Tormo, C. Couderc, M. Mercier-Bonin, P. Le Bourgeois, M. Cocaign-Bousquet, M. L. Daveran-Mingot, Microorganisms 2017, 5.

DOI: https://doi.org/10.3390/microorganisms5020027

8. A. A. Song, L. L. A. In, S. H. E. Lim, R. A. Rahim, Microb Cell Fact 2017, 16, 55.

DOI: https://doi.org/10.1186/s12934-017-0669-x

9. M. de Vrese, J. Schrezenmeir, Adv Biochem Eng Biotechnol 2008, 111, 1-66. DOI: https://doi.org/10.1007/10_2008_097

10. A. Berlec, T. Malovrh, P. Zadravec, A. Steyer, M. Ravnikar, J. Sabotic, M. Poljsak-Prijatelj, B. Strukelj, Appl Microbiol Biotechnol 2013, 97, 4333-42.

DOI: https://doi.org/10.1007/s00253-013-4722-3

11. A. Berlec, M. Ravnikar, B. Strukelj, Pharmazie 2012, 67, 891-8.

12. M. de Azevedo, M. Meijerink, N. Taverne, V. B. Pereira, J. G. LeBlanc, V. Azevedo, A. Miyoshi, P. Langella, J. M. Wells, J. M. Chatel, Vaccine 2015, 33, 4807-12.

DOI: https://doi.org/10.1016/j.vaccine.2015.07.077

13. M. Ravnikar, B. Strukelj, N. Obermajer, M. Lunder, A. Berlec, Appl Environ Microbiol 2010, 76, 6928-32.

DOI: https://doi.org/10.1128/AEM.00190-10

14. C. Michon, P. Langella, V. G. Eijsink, G. Mathiesen, J. M. Chatel, Microb Cell Fact 2016, 15, 70.

DOI: https://doi.org/10.1186/s12934-016-0468-9

15. S. Kosler, B. Strukelj, A. Berlec, Curr Pharm Biotechnol 2017, $18,318-326$.

DOI: https://doi.org/10.2174/1389201018666170210152218

16. K. Vandenbroucke, H. de Haard, E. Beirnaert, T. Dreier, M. Lauwereys, L. Huyck, J. Van Huysse, P. Demetter, L. Steidler, E. Remaut, C. Cuvelier, P. Rottiers, Mucosal Immunol 2010, 3, 49-56. DOI: https://doi.org/10.1038/mi.2009.116

17. A. Berlec, M. Perse, M. Ravnikar, M. Lunder, A. Erman, A. Cerar, B. Strukelj, Int Immunopharmacol 2017, 43, 219-226. DOI: https://doi.org/10.1016/j.intimp.2016.12.027

18. K. Leenhouts, G. Buist, J. Kok, Antonie Van Leeuwenhoek 1999, 76, 367-76. DOI: https://doi.org/10.1023/A:1002095802571

19. G. R. Visweswaran, K. Leenhouts, M. van Roosmalen, J. Kok, G. Buist, Appl Microbiol Biotechnol 2014, 98, 4331-45.

DOI: https://doi.org/10.1007/s00253-014-5633-7

20. P. Zadravec, A. Mavric, B. Bogovic Matijasic, B. Strukelj, A. Berlec, Protein Eng Des Sel 2014, 27, 21-7.

DOI: https://doi.org/10.1093/protein/gzt059

21. E. K. Call, T. R. Klaenhammer, Front Microbiol 2013, 4, 73. DOI: https://doi.org/10.3389/fmicb.2013.00073

22. S. H. Lim, F. Jahanshiri, R. A. Rahim, Z. Sekawi, K. Yusoff, Lett Appl Microbiol 2010, 51, 658-64.

DOI: https://doi.org/10.1111/j.1472-765X.2010.02950.x

23. K. Okano, Q. Zhang, S. Kimura, J. Narita, T. Tanaka, H. Fukuda, A. Kondo, Appl Environ Microbiol 2008, 74, 1117-23.

DOI: https://doi.org/10.1128/AEM.02012-07
24. G. Andre, K. Leenhouts, P. Hols, Y. F. Dufrene, J Bacteriol 2008, 190, 7079-86.

DOI: https://doi.org/10.1128/JB.00519-08

25. G. Buist, H. Karsens, A. Nauta, D. van Sinderen, G. Venema, J. Kok, Appl Environ Microbiol 1997, 63, 2722-8.

26. Y. Dieye, S. Usai, F. Clier, A. Gruss, J. C. Piard, J Bacteriol 2001, 183, 4157-66.

DOI: https://doi.org/10.1128/JB.183.14.4157-4166.2001

27. A. S. Wieczorek, V. J. Martin, Microb Cell Fact 2010, 9, 69. DOI: https://doi.org/10.1186/1475-2859-9-69

28. L. Li, J. O. Fierer, T. A. Rapoport, M. Howarth, J Mol Biol 2014, 426, 309-17. DOI: https://doi.org/10.1016/j.jmb.2013.10.021

29. S. C. Reddington, M. Howarth, Curr Opin Chem Biol 2015, 29, 94-9. DOI: https://doi.org/10.1016/j.cbpa.2015.10.002

30. S. Thrane, C. M. Janitzek, S. Matondo, M. Resende, T. Gustavsson, W. A. de Jongh, S. Clemmensen, W. Roeffen, M. van de Vegte-Bolmer, G. J. van Gemert, R. Sauerwein, J. T. Schiller, M. A. Nielsen, T. G. Theander, A. Salanti, A. F. Sander, J Nanobiotechnology 2016, 14, 30.

DOI: https://doi.org/10.1186/s12951-016-0181-1

31. K. Skrlec, A. Pucer Janez, B. Rogelj, B. Strukelj, A. Berlec, Microb Biotechnol 2017, 10, 1732-1743.

DOI: https://doi.org/10.1111/1751-7915.12781

32. P. G. de Ruyter, O. P. Kuipers, W. M. de Vos, Appl Environ Microbiol 1996, 62, 3662-7.

33. O. P. Kuipers, M. M. Beerthuyzen, R. J. Siezen, W. M. De Vos, Eur J Biochem 1993, 216, 281-91.

DOI: https://doi.org/10.1111/j.1432-1033.1993.tb18143.x

34. I. Mierau, M. Kleerebezem, Appl Microbiol Biotechnol 2005, 68, 705-17.

DOI: https://doi.org/10.1007/s00253-005-0107-6

35. P. Zadravec, B. Strukelj, A. Berlec, Appl Environ Microbiol 2015, 81, 2098-106.

DOI: https://doi.org/10.1128/AEM.03694-14

36. A. Steen, G. Buist, K. J. Leenhouts, M. El Khattabi, F. Grijpstra, A. L. Zomer, G. Venema, O. P. Kuipers, J. Kok, J Biol Chem 2003, 278, 23874-81.

DOI: https://doi.org/10.1074/jbc.M211055200

37. A. Steen, G. Buist, G. J. Horsburgh, G. Venema, O. P. Kuipers, S. J. Foster, J. Kok, FEBS J 2005, 272, 2854-68.

DOI: https://doi.org/10.1111/j.1742-4658.2005.04706.x

38. J. N. Ahmad, J. Li, L. Biedermannova, M. Kuchar, H. Sipova, A. Semeradtova, J. Cerny, H. Petrokova, P. Mikulecky, J. PoP. Sebo, P. Maly, Proteins 2012, 80, 774-89.

DOI: https://doi.org/10.1002/prot.23234

39. Z. Liu, H. Zhou, W. Wang, W. Tan, Y. X. Fu, M. Zhu, Sci Rep 2014, 4, 7266. DOI: https://doi.org/10.1038/srep07266

40. T. Bratkovic, A. Berlec, T. Popovic, M. Lunder, S. Kreft, U. Urleb, B. Strukelj, Biochem Biophys Res Commun 2006, 349, 449-53. DOI: https://doi.org/10.1016/j.bbrc.2006.08.078 


\section{Povzetek}

Predstavitev rekombinantnih proteinov na bakterijski površini postaja pomembno raziskovalno področje s številnimi možnostmi uporabe na področju biotehnologije. Zaradi statusa GRAS (generally recognized as safe - splošno priznana kot varna) predstavlja mlečnokislinska bakterija Lactococcus lactis privlačen gostiteljski organizem za površinsko predstavitev in obetaven vektor za in situ dostavo proteinov. Opisana raziskava se je osredotočila na iskanje novega alternativnega pristopa za površinsko predstavitev na bakteriji Lactococcus lactis. Razvili smo sistem, ki omogoča tvorbo ireverzibilne izopeptidne vezi na površini bakterije Lactococcus lactis. To smo dosegli s pomočjo dveh parov protein/ peptid, SpyCatcher/SpyTag in SnoopCatcher/SnoopTag. ${ }^{1-3}$ Pritrditev modelnega proteina domene B na površino bakterij Lactococcus lactis, ki so imele na površini ustrezen lovilni protein, smo potrdili s pretočno citometrijo. V raziskavi smo prikazali učinkovito uporabo omenjenih proteinskih sidrnih domen, ki tako predstavljajo potencialno alternativo obstoječim načinom površinske predstavitve na bakteriji Lactococcus lactis. 